Maria Chernysheva, Mimesis v izobrazitel'nom iskusstve: ot grecheskoi klassiki do frantsuzskogo siurrealizma (Mimesis in visual arts from Greek classic to French surrealism)

\author{
St Petersburg: St Petersburg State University, 2014, 392 pp., \\ ISBN 978-5-288-05511-9 \\ Reviewed by Artemy Magun \\ European University at St Petersburg
}

\title{
Ab Realibus ad Realiora: Maria Chernysheva's Mimesis in the Visual Arts
}

Mimesis is a basic aesthetic category that is especially significant in the early modern period and the twentieth century. The Greek word carries two meanings: the repetition of a thing existing in reality (a model) and, at the same time, the enactment of that thing through play. The onomatopoeic doubling of its root signifies both an aping (tit for tat) and a certain flamboyance of the play that results (la-la).

It is strange that art, that is the sphere of the emphatically unreal, is defined by the imitation of the real. In the nineteenth and twentieth centuries it even becomes identified with "realism" itself. Herein lies an interesting contradiction. It is impressive when a copy of a familiar thing or person appears-seemingly real, but actually fake. We encounter a thing but its presence is subtracted. This works-one can shield oneself from the threatening presence of a thing and engage with it at the same time. However, it is not just the resemblance that acts as the aesthetic agent-its ornamental quality does, too: it contains properties of resemblance, but these gradually fade, leaving behind only play. This is a kind of "next step": after disposing of the materiality of a thing, we dispose of its resemblance.

Theorizing about this topic has been fraught with irony. Plato called the art of his time imitative, that is, only imitation and nothing else. That is to say art has nothing of its own: it has a parasitic relationship to "reality," but a less effective one, evidently, than does science. And yet this is the thing that art can call its own: the disruption and destruction of ideal truth give birth to various emotions, which, independently of their "sign," 
derive from the negativity of the experience. It is these emotions that consolidate the existence of art.

It seems it would be necessary, having rejected Plato, to then acquit art, having separated it from scientific and photographic tasks, and bequeathed to it the sphere of the "unreal"-play, fantasy, imagination. And indeed this has been undertaken in the past: by Philostratus in Greece, by Immanuel Kant and Friedrich Schiller in the modern period, and in our time by Clement Greenberg. Nonetheless, at least in antiquity the dominant understanding of aesthetic behavior was that it was of external origin. Hence the endless back-and-forth between art and external reality, and hence, among other things, Aristotle's compromise. Aristotle accepts Plato's definition of art as mimesis, but alters it dialectically (reflection and overturning): for him, mimesis is not so much the imitation of an existing model as it is the imitation of imitation: creating an image that acts as if it is imitating some existing model, but in fact there is no such model-rather, one is created illusionistically as a retrospective projection of the image. For this to happen, it is still necessary to imitate nature, but not nature as that which has become-instead, it is necessary to imitate that in nature which is power and lack, which art can then complete using its own means. One can say, as Maria Chernysheva does, that Aristotle makes apparent here a special type of mimesis, the "poietic," creative type.

The product of art, according to Aristotle, is once again a dialectical reversal of the negative passions described by Plato: their imitation is indeed provocative, but the imitation of imitation, which does not pretend to model the external world, relieves those passions using those very passions: fear and compassion, lacking an object, turn in on themselves and become less fearsome, more rationally acceptable and knowable.

Later in antiquity, there appeared an anecdote on this subject, relayed by Pliny, concerning a competition between Zeuxis and Parhassius. One of them drew a naturalistic image of grapes; the other drew a curtain behind which a painting appeared to hang, but in fact did not. Art is the imitation of imitation. It is rarely noted that this legend illustrates Aristotelian reflexive poetics.

During the High Middle Ages and Renaissance, until the sixteenth century, Aristotle's Poetics was not particularly well known (there was no widely available Latin translation). Dominant during this time period was a kind of inverted Platonism: art as both the imitation of models and as modeling itself, even though Plato condemned the former, and thought the latter to be the province of transcendent eidoi. What is depicted is the idea of reality, although, as Erwin Panofsky (1968) showed, there was an attempt made in the fiftteenth and sixteenth centuries to derive the idea from the study of nature itself, rather than receive it from on high. In Chernysheva's words, an "ideal mimesis" occurs, whereby art competes with nature and surpasses it in its ideality, to the point of claiming the place of the ideal model (e.g., in modernist aesthetic myths and religions 
of art). At the same time, as Chernysheva writes (with Filippo Villani in mind), Renaissance theory and painting depart from Plato and shift towards Aristotle and Philostratus in that they consider the goal of art not to be the reproduction of truth, but rather the creation of verisimilitudes (54). However, here it is necessary to clarify that, at least until the seventeenth century, this mode of painting is dominated not by fictitious but lofty, religious-biblical and ancient-subjects.

In the seventeeth to nineteenth centuries, the ideal form became more grounded with the addition of mundane details, which emulated material things, this time without their idealization (naturalism and "realism"). However, it turned out, paradoxically, that the precise, literal transfer of experience involves a corruption of the form (impressionism).

In the twentieth century, another key shift occurred in the paradigm of mimesis: it was discovered, through evidence from ancient texts and anthropological finds, that mimesis-before, and independently of, Plato-referred to the activity of the mime, that is, expression, as well as spontaneous emotional contamination. Some of the most important twentieth-century works on aesthetics (Caillois, Girard, Adorno, Lacoue-Labarthe) are devoted to this subject.

The word mimesis has two meanings, which are both represented in art. This means that a particular ambiguity is inherent to the term from the start: mimesis as the reproduction of things and mimesis as the emotional reaction to them, which echoes their strength, habit, but not their external guise. This would explain why "impression" in the nineteenth century becomes "expression" in the twentieth.

It is now evident that throughout history there have existed two opposing tendencies. On the one hand, the search for ever new forms of transmitting reality. On the other hand, ever new ways of departing from "reality," that is, from one or another of its forms.

In her recent book, Mimesis v izobrazitel'nom iskusstve: ot grecheskoi klassiki do frantsuzskogo siurrealizma (Mimesis in visual arts from Greek classic to French surrealism), Maria Chernysheva meticulously traces both tendencies in the plastic arts. With regard to mimesis as the meticulous transmission of an object (in maximum detail, to the point of trompe l'oeil), Chernysheva presents a whole range of interpretations and uses. Thus, in Medieval and Renaissance painting, "naturalistic" verisimilitude is used for rendering mystical or hallucinatory visions. The abundance of details, representing one of the main techniques of realism up to the twentieth century, does not just reflect an object, but, in fact, creates a hypnotic effect on account of diffusing the viewer's gaze and immersing them into the painting (78-79).

Until as late as the nineteenth century, natural likeness signified a grounding of the ideal. Vegetables and fruits could be drawn with deceptive verisimilitude, but not people. People had to be ideal and even $a b-$ stractly structural. Caravaggio was scorned for his "dastardly" naturalism, 
which he used to achieve the effect of firmness and corporeality (i.e., materiality) in the image.

Chernysheva tells us that the fairly naturalistic Dutch painting of the seventeenth century resorted to painting the mundane in a grounded, comedic way. Brueghel's grotesque is of the same nature as his "realism." It is no coincidence that Rembrandt, whose style is completely different, focuses primarily on biblical subjects and portraits of respectable individuals (192-93). It is from here that we get the realism of the nineteenth century: after all, it was a realism not only, and not so much, of technique as of content: the lowly and the mundane were now upheld as most valuable. Nature and daily life remain true to themselves, while the higher, lofty level is cut off. Gustave Courbet, the leader of this movement, wrote that "the essence of realism is its negation of the ideal" (307). His realism was not simply naturalism, but also intentionally included naively primitivistic traits. Negation becomes a strong element of mimesis, making it not only figurative but also symbolic: a primitive drawing is not a copy, but a sign of the material as a grounded form. Moreover, Courbet's negation can drop below zero to the level of chthonic demonism, which Chernysheva astutely recognizes in the now-famous L'Origine $d u$ Monde (where a vagina is depicted in close-up). Here, she writes, "realism no longer triumphs, but overcomes itself" (314).

Conversely, from the earliest stages of the development of art, we can observe a certain disembodiment and disaggregation-that is, departure from the form, from any faithfulness to the "original" and any verisimilitude. This is not done by chance or whim, but consciously and with clear expressive goals in mind. What in the twentieth century became deliberate "abstraction" or aimlessness had been present earlier for all sorts of reasons. For example, the fuzziness and continuity of Leonardo da Vinci's figures, so-called sfumato, is understood as a representation of "nothingness" in the Neoplatonic sense (99-100). The Mannerists' violation of the mimetic form is deliberate, and Chernysheva goes so far as to say they "devalue mimesis" as part of their technique (however, this only holds true for the old meaning of mimesis, and not the contemporary, expressive meaning) (133). One very interesting example is Velasquez, whose wonderful imitation occurs through "the dematerialization of bodies by the ethereal environment" (174) and the "aristocratic" nonchalance and grace of style, which gives an image the effect of naturalness, not in the sense of faithfulness to nature, but in the sense of spontaneity of existence.

"This type of presentation ... interprets the world not as having been constructed inside a painting by the efforts of the artist-viewer, but as voluntarily reflected on the surface of the painting independently of the will of the artist-viewer" (181).

In the bourgeois period, a similar negligence is practiced by the impressionists and Baudelaire. Not being aristocrats, but merely wishing to 
take their place, bourgeois artists are able to reproduce the lightness of style only by radically disembodying their subjects, increasing the degree of subjectivity with which they are represented. Velasquez, on the other hand, feeling more confident, manages to preserve both the objectivity and universality of content.

Herein lies a paradox (although Chernysheva does not emphasize this point) that returns us to antiquity, to Aristotle, as well as to Longinus: genuine imitation should not only replicate nature or complement it, but rather should lift this nature, as if it were its own heavy materiality, having properly processed it beforehand. Action, manner, and play gradually subordinate one's fixation on an object, one's passive possession by it. (Cf. my earlier comment regarding mimesis as a means of neutralizing and distancing an image by cleansing it of its materiality.)

Twentieth-century modernism, as we know, was a highly varied phenomenon. The rejection of traditional nineteenth-century realism by no means entailed a rejection of mimesis in general, or of the representation of objects in particular. Of course, the most radical wing of modernism called for a rejection of objective mimesis in favor of pure form (Hildebrandt) or abstraction (Worringer). This preference had three basic motivations: to leave art to its own devices (autonomy), to express the dissonance between the subject and the world, and to transcend the world spiritually. It cannot be said that, in and of themselves, abstraction and aimlessness were unprecedented. We can see that art constantly maneuvers between two poles-obsession with things and their dismissal, that is, their submission to the active "poiesis" (creation) of the artist. Modernists radicalized both positions, and many of them were driven both by formalism and ultra-naturalism (e.g., stream of consciousness literature). Even today, for example, the lure of auteur cine$m a$ is not so much its avant-garde form as it is its uncontrollable flow of experience. Chernysheva's book shows that art, or at least painting, succeeds when it works at the intersection of these two forces: aimless art quickly loses attractiveness when the object it destroys becomes forgotten.

Modernism prevailed in the twentieth century, but not without stirring up debate: Chernysheva performs an in-depth examination of premimetic propaganda by Georg Lukács, one of the creators of the Soviet aesthetic theory of socialist realism. Lukács is generally astute in his critique of modernism as a combination of extreme naturalism and extreme formalism, seeing in both a rejection of understanding reality. He also correctly reminds us that mimesis and realism are not reducible to naturalism, but rather presume a holistic vision of reality correlated with the ideal. However, in Chernysheva's opinion, Lukács in fact proposes to reincarnate classicist aesthetics, and his failure in this regard (very little was accomplished in this genre) speaks to the fact that we do not currently have an ideal horizon for their renaissance. 
We have to agree. In the twenty-first century we have indeed encountered the exhaustion of the possibly destructive, possibly rebellious, possibly spiritualistic program of the avant-garde. This exhaustion has manifested in the splitting of art into the categories of mass and "elite," and in the displacement of representational art by the so-called modern, which subordinates it to situational forms of expression (theater, photography, documentary film). We are ripe for a synthesis, which would introduce virtuously expressive and playful elements into the form of serious, complex contemplation of modernity. But are painting, sculpture, or even Lukács's beloved novel capable of this kind of synthesis, or must it be realized by film and the circus? Must this synthesis be realistic, or will it be closer to the creation of a total installation, a parallel world, an heir not to realism nor twentieth-century modernism, but to late nineteenth-century symbolism, with its naturalistic fantasy? Incidentally, Chernysheva's book, true to tradition, dismisses symbolism as secondary. This is a shame, because we are living in a time when symbolism is becoming increasingly relevant, as we can see from the popularity of its derivatives in mass culture. Nevertheless, this book about the history of mimesis gives us all the elements of its polymorphous richness, so that in the future we can dream about new art while imitating the old.

\section{Bibliography}

Panowsky, Erwin (1968). Idea: A Concept in Art Theory. Columbia: University of South Carolina Press. 